\title{
PROBLEMATIKA HUKUM ARBITRASE ONLINE MENURUT UU NO. 30 TAHUN 1999 TENTANG ARBITRASE DAN ALTERNATIF PENYELESAIAN SENGKETA
}

\author{
Ilham Bagaskara Aji \\ E-mail: Ilham_bagas90@gmail.com \\ Mahasiswa Fakultas Hukum Universitas Sebelas Maret Surakarta \\ Pujiyono \\ E-mail: pujifhuns@gmail.com \\ Dosen Fakultas Hukum Universitas Sebelas Maret Surakarta
}

\begin{abstract}
This article describes and examines the problem, first, the legal standing of the Arbitration Online according to Law No. 30 of 1999 concerning Arbitration and Alternative Dispute Resolution. Secondly, there are legal problems if online arbitration is carried out in Indonesia. This research is prescriptive normative legal research. Types of data and sources of research material include primary and secondary legal materials. The data collection technique used is the study of literature and through Cyber media, furthermore the technical analysis used is the deductive method. The results show that online arbitration can actually be carried out in Indonesia. Through Law No. 11 of 2008 concerning Electronic Information and Transactions that were changed using Law No. 19 of 2016 concerning Amendments to Law No. 11 of 2008 and Government Regulation No. 71 of 2019 concerning the Implementation of Electronic Transactions and Systems the government has provided the means and foundation for carrying out online arbitration. Online arbitration has advantages in the speed and efficiency of dispute resolution times. However, online Aribtrase also has some disadvantages such as how to registering decisions in court, the presence of witnesses in court, piracy and hacking, and unequal electronic means.
\end{abstract}

Keywords: Alternative Dispute Resolution; Online Arbitration; Electronic Document; Law No. 30 of 1999

\begin{abstract}
Abstrak
Artikel ini ini mendeskripsikan dan mengkaji permasalahan, pertama, kedudukan hukum Arbitrase Online menurut UU No. 30 Tahun 1999 tentang Arbitrase dan Alternatif Penyelesaian Sengketa. Kedua, problem hukum apabila arbitrase online dilaksanakan di Indonesia. Penelitian ini adalah penelitian hukum normatif bersifat preskriptif. Jenis data dan sumber bahan penelitian meliputi bahan hukum primer dan sekunder. Teknik pengumpulan data yang digunakan adalah studi kepustakaan dan melalui Cyber media, selanjutnya teknis analisis yang digunakan adalah metode deduktif. Hasil penelitian menunjukkan bahwa arbitrase online sebenarnya sudah dapat dilaksanakan di Indonesia. Melalui Undang- Undang No. 11 Tahun 2008 tentang Informasi dan Transaksi Elekronik yang diubah menggunakan Undang- Undang No. 19 Tahun 2016 tentang Perubahan Atas Undang- Undang No. 11 Tahun 2008 serta Peraturan Pemerintah No. 71 Tahun 2019 tentang Pelaksanaan Sistem dan Transaksi Elektronik pemerintah telah memberikan sarana dan landasan untuk melaksanakan arbitrase online. Arbitrase online memiliki kelebihan dalam kecepatan dan efisiensi waktu penyelesaian sengketa. Akan tetapi arbitrase online juga memiliki beberapa kekurangan seperti bagaimana pendaftaran putusan di pengadilan, kehadiran para saksi dalam persidangan, pembajakan dan peretasan, dan sarana elektronik yang kurang merata.
\end{abstract}

Kata Kunci: Alternatif Penyelesaian Sengketa; Arbitrase Online; Dokumen Digital; UU No. 30 Tahun 1999

\section{A. Pendahuluan}

Dewasa ini, banyak sekali kegiatan perdagangan, penanaman modal, perbankan yang dilakukan menggunakan sarana internet. Sejalan dengan semakin banyaknya kegiatan yang 
digunakan dengan media internet, maka semakin banyak pula permasalahan yang muncul akibat dari kegiatan tersebut. Penyelesaian sengketa dapat dibagi menjadi dua yaitu penyelesaian sengketa melalui pengadilan dan penyelesaian sengketa di luar pengadilan.

Seperti yang diutarakan oleh Ketua Mahkamah Agung (MA), perkara yang ditangani MA tahun 2018 sebanyak 18.544, yang terdiri dari perkara masuk tahun 2018 sebanyak 17.156 dan sisa perkara tahun 2017 sebanyak 1388 perkara. MA berhasil memutus sebanyak 17.638 perkara, sehingga sisa perkara yang belum diputus pada akhir tahun 2018 sebanyak 906 perkara. Jika dibandingkan dengan tahun 2017, jumlah perkara yang diterima (di-register) meningkat $10,65 \%$, jumlah beban perkara meningkat $3,82 \%$, jumlah perkara yang diputus meningkat $7,07 \%$, sedangkan jumlah sisa perkara berkurang34,73\%. (Asep Nursobah, https://kepaniteraan.mahkamah agung. go.id/index.php/kegiatan/1625-penanganan-perkara-mahkamah-agung-2018-mencetak-rekorbaru-pencapaian-terbaik-sepanjang- sejarah-ma, diakses pada 28 Oktober 2019 pukul 12.00). Penyelesaian sengketa bisnis melalui pengadilan resmi, pada umumnya memakan waktu lama dan membutuhkan biaya yang besar karena faktor prosedur sistem peradilan sangat kompleks dan berbelit-belit. Bahkan untuk suatu kasus dapat dibutuhkan waktu bertahun-tahun untuk menyelesaikan sengketa sampai pada putusan hakim dibacakan.

Hal itu membuat proses penyelesaian sengketa mereka menjadi sangat tidak efektif dan efisien. Terlebih jika para pihak mempunyai kesibukan sendiri sehingga hanya punya waktu terbatas untuk mengikuti proses penyelesaian sengketa. Di samping itu, kalangan dunia bisnis beranggapan penyelesaian sengketa di bidang bisnis, kurang dipahami oleh para hakim jika dibanding dengan mereka yang berkecimpung dengan dunia bisnis itu sendiri. Apalagi jika para pihak yang bersengketa adalah warga negara yang berbeda, Indonesia di satu sisi dan negara asing di pihak lain, muncul beberapa pernyataan seperti pengadilan negara mana yang berwenang untuk memeriksa perkara, hukum mana yang dapat digunakan, lalu mengingat akibat perbedaan yurisdiksi, maka putusan badan peradilan negara asing tidak dapat dieksekusi di Indonesia. Oleh karena itu alternatif penyelesaian sengketa di luar pengadilan menjadi dibutuhkan. Di Indonesia ada beberapa bentuk alternatif penyelesaian sengketa yang terdapat dalam Pasal 1 butir 10 UndangUndang Nomor 30 Tahun 1999 tentang Arbitrase dan Alternatif Penyelesaian Sengketa (AAPS) yaitu konsultasi, negosiasi, mediasi, konsiliasi, atau penilaian ahli.

Dalam UU No 30 tahun 1999 terdapat pengertian tentang Arbitrase yaitu cara penyelesaian suatu sengketa perdata di luar peradilan umum yang didasarkan pada perjanjian arbitrase yang dibuat secara tertulis oleh para pihak yang bersengketa. Pihak ketiga yang dimaksud biasa disebut dengan istilah Arbiter. Arbiter sebagai pihak ketiga yang menengahi menjalankan tugasnya dan menyelesaikan sengketa dengan cara memberikan putusan.

Perkembangan zaman dan teknologi yang semakin cepat dan maju juga membuat pelaksanaan arbitrase semakin mudah dan cepat. Dan dimungkinkannya adanya pelaksanaan beracara arbitrase secara online. Upaya penyelesaian sengketa arbitrase online sudah mulai dikenal dan diberlakukan di negara-negara maju seperti Amerika, Inggris, Kanada dan beberapa negara di Eropa.

Di Indonesia sendiri sebenarnya sudah terbuka jalan untuk melaksanakan arbitrase secara online yang terdapat dalam Pasal 31 ayat (1) UU Nomor 30 Tahun 1999. Berdasarkan pasal tersebut, para pihak dapat menentukan sendiri bentuk acara dalam proses arbitrase, termasuk dengan melangsungkan arbitrase secara online menggunakan sarana internet. Kemudian, menurut Pasal 4 ayat (3) Undang-Undang Nomor 30 Tahun 1999 penyelesaian sengketa melalui arbitrase terjadi dalam bentuk pertukaran surat, maka pengiriman teleks, telegram, faksimili, e-mail, atau dalam bentuk sarana komunikasi lainnya, wajib disertai dengan suatu catatan penerimaan oleh para pihak. Dalam hal ini timbul permasalahan tentang keaslian dari dokumen dokumen yang dikirim dan digunakan dalam beracara. Karena dengan kemajuan teknologi seperti sekarang ini, pembajakan, perubahan dan penghapusan dokumen menjadi sangat mudah dan cepat dilakukan.

Berdasarkan uraian di atas artikel ini membahas Problematika Hukum Arbitrase Online Menurut Undang-Undang No. 30 Tahun 1999 tentang Arbitrase dan Alternatif Penyelesaian Sengketa". 


\section{B. Metode Penelitian}

Penelitian mengenai problematika hukum arbitrase online menurut UU No. 30 tahun 1999 tentang Arbitrase dan Alternatif Penyelesaian Sengketa ini merupakan penelitian hukum normatif yaitu penelitian yang mengacu kepada peraturan perundang- undangan yang berlaku di Indonesia. (Peter Mahmud Marzuki, 2013: 32).

Sifat dari penelitian ini adalah preskriptif untuk menjawab isu hukum yang diangkat dengan argumentasi, teori, atau konsep baru sebagai preskripsi dalam menyelesaikan permasalahan mengenai problematika hukum arbitrase online menurut UU No. 30 tahun 1999 tentang Arbitrase dan Alternatif Penyelesaian Sengketa (Peter Mahmud Marzuki, 2013: 32).

Untuk menjawab permasalahan dilakukan pengumpulan bahan hukum melalui studi kepustakaan yang meliputi bahan hukum primer yaitu Undang-Undang No. 30 Tahun 1999 tentang Arbitrase dan Alternatif Penyelesaian Sengketa, Kitab Undang- Undang Hukum Perdata, UndangUndang 11 Tahun 2008 Informasi dan Transaksi Elektronik, Undang-Undang No. 19 Tahun 2016 tentang Perubahan atas Undang- Undang 11 Tahun 2008 Informasi dan Transaksi Elektronik, Peraturan Pemerintah No 71 Tahun 2019 tentang Pelaksanaan Sistem dan Transaksi Elektronik dan bahan hukum sekunder yaitu buku-buku teks yang ditulis oleh para ahli hukum, Internet, Jurnal Hukum, Sumber lainnya yang memiliki korelasi untuk mendukung penelitian ini.

Teknik analisis yang dilakukan adalah metode silogisme deduktif yaitu berpangkal dari pengajuan premis mayor kemudian diajukan premis minor, dari kedua premis ini kemudian ditarik kesimpulan (Peter Mahmud Marzuki, 2014: 89).

\section{Hasil Penelitian dan Pembahasan}

1. Kedudukan Arbitrase Online menurut Undang-Undang No. 30 Tahun 1999

Sebelum membahas tentang arbitrase online maka kita perlu membahas arbitrase menurut Undang-Undang No. 30 Tahun 1999. Pasal 1 Angka 1 Undang- Undang No. 30 tahun 1999 tentang Arbitrase dan Alternatif penyelesaian sengketa, menyebutkan bahwa arbitrase adalah cara penyelesaian suatu sengketa perdata di luar pengadilan umum yang didasarkan pada perjanjian arbitrase yang ditulis oleh para pihak yang bersengketa.

Pasal 5 ayat (1) UU Nomor 30 Tahun 1999 tentang Arbitrase dan Alternatif Penyelesaian Sengketa menjelaskan tentang sengketa yang dapat diselesaikan melalui arbitrase hanya sengketa di bidang perdagangan dan mengenai hak yang menurut hukum dan peraturan perundang-undangan dikuasai sepenuhnya oleh pihak yang bersengketa. Selain itu, arbitrase memiliki kelebihan seperti putusannya bersifat tertutup untuk umum sehingga nama dan kredibilitas dari para pihak tetap terjaga untuk menjaga kelangsungan dari suatu usaha/bisnis, mengurangi penumpukan perkara di pengadilan, lebih efektif dan efisien baik dari segi waktu maupun segi biaya serta putusannya bersifat final and binding artinya putusan tersebut tidak dapat dimintakan banding dan kasasi dan putusan tersebut mengikat secara sukarela dengan itikad baik karena sebelum putusan dibuat mereka juga telah sepakat untuk menyelesaikannya melalui jalur arbitrase dengan segala konsekuensinya.

Karena Undang-Undang No. 30 Tahun 1999 tidak mengatur bagaimana proses beracaranya melainkan cara itu diserahkan pada para pihak sebagaimana Pasal 31 UU No. 30 tahun 1999 maka pelaksanaan arbitrase online sangat dimungkinkan. Dalam Undang-Undang Nomor 30 Tahun 1999 tidak memberikan batasan tentang bentuk apa yang harus digunakan yaitu harus tercetak atau tidak, hanya memberi batasan bahwa perjanjian tersebut secara tertulis. Dalam undang-undang tersebut juga tidak mengatur mengenai bahan atau media apa yang digunakan untuk menulis perjanjian tersebut. dalam penyelesaian sengketa melalui arbitrase konvensional mendasarkan kegiatan pada pertukaran dan pemeriksaan dokumen bermedia kertas (paperbase), sementara itu, dalam arbitrase online media kertas telah digantikan oleh data digital (Hetty Hassanah, 2010:103). 
Pasal 4 ayat (3) Undang-Undang Nomor 30 Tahun 1999 tentang Arbitrase dan Alternatif Penyelesaian Sengketa menyatakan bahwa dalam hal disepakati penyelesaian sengketa melalui arbitrase terjadi dalam bentuk pertukaran surat, maka pengiriman telegram, faksimili, e-mail, atau dalam bentuk sarana komunikasi lainnya, disertai dengan suatu catatan penerimaan oleh para pihak. Dengan demikian, maka para pihak tidak diwajibkan untuk hadir selama proses arbitrase dengan syarat para pihak telah mengadakan kesepakatan sebelumnya, sehingga apabila para pihak tidak dapat bertatap muka secara langsung dalam proses penyelesaian sengketa melalui arbitrase bukan merupakan suatu permasalahan (Rizky Novian Margono, 2013:5).

Menurut Munir Fuadi (dikutip dari Sarah Meilita Indrani Jurnal Privat Law Vol. V No 2 Juli-Desember 2017) arbitrase online merupakan pengembangan dari bentuk arbitrase konvensional, bertujuan menyelesaikan sengketa yang terjadi di antara para pihak yang telah melakukan suatu perjanjian dalam ruang lingkup hukum perdata. Perbedaan mendasar yang membedakan antara perjanjian konvensional dengan perjanjian dalam bentuk elektronik atau online, adalah terletak pada physical form (bentuk konkrit dan nyata) pada perjanjian konvensional dan pada perjanjian online penawaran serta penerimaan dilaksanakan dalam bentuk elektronik, disamping itu sifat perjanjian online secara umum adalah non-face yang berarti bahwa tidak membutuhkan physical presence (kehadiran secara fisik) dan paperless. Sehingga dapat dirumuskan suatu pengertian arbitrase online yakni suatu pelaksanaan arbitrase yang dilakukan menggunakan sara internet dan tidak bertemu secara langsung.

Pasal 31 ayat (1) Undang- Undang Arbitrase dan penyelesaian sengketa sebenarnya dapat menjadi dasar untuk penyelesaian sengketa arbitrase secara elektronik/online. Pasal tersebut menyatakan "Para pihak dalam suatu perjanjian yang tegas dan tertulis, bebas untuk menentukan acara arbitrase yang digunakan dalam pemeriksaan sengketa sepanjang tidak bertentangan dengan ketentuan dalam Undang-undang ini.". Berdasarkan pasal tersebut dapat ditarik kesimpulan bahwa arbitrase dapat dilaksanakan secara elektronik jika terdapat kesepakatan terlebih dahulu dari para pihak yang bersengketa untuk melaksanakan arbitrase secara online. Apabila arbitrase dilaksanakan secara online, maka pelaksanaan pemeriksaan tentu menggunakan sarana surat dan dokumen elektronik, hal ini sudah diatur dengan pasal 4 ayat (3) yang berbunyi "Dalam hal disepakati penyelesaian sengketa melalui arbitrase terjadi dalam bentuk pertukaran surat, maka pengiriman teleks, telegram, faksimili, e-mail atau dalam bentuk sarana komunikasi lainnya, wajib disertai dengan suatu catatan penerimaan oleh para pihak" dalam pasal tersebut dapat ditarik kesimpulan bahwa pertukaran dokumen menggunakan sarana elektronik boleh dilaksanakan menurut Undang- Undang No. 30 tahun 1999.

Undang- Undang No 11 tahun 2008 tentang Informasi dan Transaksi Elektronik (UU ITE) dalam pasal 5 ayat (1) dan (2) menyatakan bahwa informasi dan/ataur dokumen elektronik merupakan alat bukti yang sah dan merupakan perluasan dari dari alat bukti yang sah menurut Hukum Acara yang berlaku di Indonesia. Pasal 6 UU ITE memberikan syarat tentang dokumen elektronik dapat dianggap sah apabila suatu informasi harus berbentuk tertulis atau asli dan informasi yang tercantum di dalamnya dapat diakses, ditampilkan, dijamin keutuhannya, dan dapat dipertanggungjawabkan sehingga menerangkan suatu keadaan.

Pasal 1 ayat (4) Undang- Undang ITE menjelaskan bahwa dokumen yang digunakan dalam transaksi elektronik dinamakan dengan "dokumen elektronik" artinya adalah setiap Informasi Elektronik yang dibuat, diteruskan, dikirimkan, diterima, atau disimpan dalam bentuk analog, digital, elektromagnetik, optikal, atau sejenisnya, yang dapat dilihat, ditampilkan, dan/ atau didengar melalui Komputer atau Sistem Elektronik, termasuk tetapi tidak terbatas pada tulisan, suara, gambar, peta, rancangan, foto atau sejenisnya, huruf, tanda, angka, Kode Akses, simbol atau perforasi yang memiliki makna atau arti atau dapat dipahami oleh orang yang mampu memahaminya. 
Kemudian muncul pertanyaan, apakah dokumen elektronik tersebut diakui dalam hukum perdata dan dapat digunakan dalam berarbitrase nantinya mengingat dalam hukum perdata hanya dikenal 5 jenis alat bukti yang terdapat dalam Pasal 164 RBG yaitu:

1. Surat

2. Saksi

3. Persangkaan

4. Pengakuan

5. Sumpah

Undang-undang ITE dalam pasal 5 ayat (1) menyatakan bahwa "Informasi Elektronik dan/atau Dokumen Elektronik dan/atau hasil cetakannya merupakan alat bukti hukum yang sah". Ayat (2) menyatakan "Informasi Elektronik dan/atau Dokumen Elektronik dan/atau hasil cetaknya sebagaimana dimaksud pada ayat (1) merupakan perluasan dari alat bukti yang sah sesuai dengan Hukum Acara yang berlaku di Indonesia". Berdasarkan Pasal 5 ayat (1) dan (2) Undang-undang ITE tersebut maka dokumen elektronik dapat digunakan dalam proses berarbitrase. Namun demikian menurut Pasal 5 ayat (4) Undang-undang ITE menyatakan bahwa tak semua surat atau akta dapat dibuat secara elektronik. Surat atau akta yang tidak boleh dibuat secara elektronik yaitu:

1. Surat yang menurut undang-undang harus dibuat dalam bentuk tertulis

2. Dokumen yang menurut undang-undang harus dibuat dalam bentuk akta notaris atau akta yang dibuat oleh Pejabat Pembuat Akta Tanah (PPAT).

Dokumen eletronik atau informasi elektronik dianggap sah sepanjang informasi atau dokumen dapat diakses, ditampilkan, dijamin keutuhannya dan dapat dipertanggungjawabkan sehingga menerangkan suatu keadaan. Untuk itu, sepanjang dokumen elektronik dapat dipertanggungjawabkan kebenarannya secara formil dan materiil serta kesesuaiannya dengan peraturan perundang-undangan maka dapat dijadikan sebagai alat bukti yang sah.

Salah satu cara untuk memverifikasi agar dokumen elektronik tersebut adalah asli dan dapat dipertanggungjawabkan kebenarannya secara formil dan materiil adalah dengan cara membubuhi tanda tangan elektronik di dalamnya.

Pasal 1 angka 13 Undang- undang ITE menyatakan Tanda Tangan Elektronik adalah tanda tangan yang terdiri atas Informasi Elektronik yang dilekatkan, terasosiasi atau terkait dengan Informasi Elektronik lainnya yang digunakan sebagai alat verifikasi dan autentikasi. Lebih lanjut pengaturan mengenai tanda tangan elektronik berada dalam Pasal 59 sampai 64 Peraturan Pemerintah No 71 Tahun 2019 tentang Pelaksanaan Sistem dan Transaksi Elektronik. Tanda tangan elektronik yang mewakili badan usaha maka disebut sebagai segel elektronik. Tanda tangan elektronik berfungsi sebagai alat autentikasi dan verifikasi atas identitas penanda tangan dan keutuhan dan keautentikan informasi elektronik.

Tanda tangan elektronik memiliki syarat sah agar memiliki kekuatan hukum seperti yang dijelaskan dalam Pasal 11 ayat (2) Undang-Undang No. 11 Tahun 2008 tentang Informasi dan Transaksi Elektronik jo. Pasal 59 ayat (3) Peraturan Pemerintah No 71 Tahun 2019 tentang Pelaksanaan Sistem dan Transaksi Elektronik, yaitu:

1. Data Pembuatan Tanda Tangan Elektronik terkait hanya kepada Penanda Tangan;

2. Data Pembuatan Tanda Tangan Elektronik pada saat proses penandatanganan elektronik hanya berada dalam kuasa Penanda Tangan;

3. segala perubahan terhadap Tanda Tangan Elektronik yang terjadi setelah waktu penandatanganan dapat diketahui;

4. segala perubahan terhadap Informasi Elektronik yang terkait dengan Tanda Tangan Elektronik tersebut setelah waktu penandatanganan dapat diketahui; 
5. terdapat cara tertentu yang dipakai untuk mengidentifikasi siapa Penanda Tangannya; dan

6. terdapat cara tertentu untuk menunjukkan bahwa Penanda Tangan telah memberikan persetujuan terhadap Informasi Elektronik yang terkait.

UU ITE dan perubahannya dan PP No. 71 tahun 2019 memberikan pengakuan secara tegas bahwa meskipun hanya merupakan suatu kode, tanda tangan elektronik memiliki kedudukan yang sama dengan tanda tangan manual pada umumnya yang memiliki kekuatan hukum dan akibat hukum.

Terdapat beberapa keuntungan apabila arbitrase online dilakukan di Indonesia (Paustinus Siburian, 2004:110-111):

a. Penghematan waktu dan uang. Penyelesaian sengketa secara online akan lebih menghemat dibandingkan alternatif penyelesaian sengketa secara tradisional, karena para pihak tidak perlu membayar biaya yang harus dikeluarkan untuk menghadiri persidangan dan biaya-biaya yang berkaitan dengan hal itu.

b. Bagi para konsumen yang menghindari biaya besar dalam penyelesaian sengketa, tentu akan lebih mudah menerima penyelesaian sengketa secara elektronik karena mereka dapat mengerjakannya sendiri dengan fasilitas komputer yang dimiliki.

c. Para pihak yang menggunakan akses internet lebih yakin dalam menghadapi proses yang akan dijalaninya, sebab mereka dapat dengan mudah mengontrol dan merespons apa yang terjadi dalam proses.

d. Dapat menghindari pertemuan dengan pihak lawannya. Hal ini merupakan persoalan psikologis.

e. Keuntungan lainnya yang mungkin didapatkan oleh pihak lain, seperti vendor software (pembuat software).

2. Problem Hukum Apabila Arbitrase Online Dilaksanakan di Indonesia

Arbitrase dan alternatif penyelesaian sengketa lainnya secara online tidak jauh berbeda dari arbitrase dan alternatif penyelesaian sengketa secara "tradisional". Perbedaannya hanyalah mengenai cara yang digunakan, yaitu penggunaan sarana-sarana elektronik dalam penyelenggaraannya. Dalam arbitrase online, pendaftaran perkara, pemilihan arbiter, penyerahan dokumen-dokumen, permusyawarahan para arbiter dalam hal tribunal arbitrase lebih dari seorang arbiter, pembuatan putusan, serta pemberitahuan akan adanya putusan dilakukan secara online.

Permasalahan yang perlu diperhatikan dalam pelaksanaan arbitrase online antara lain dalam hal:

\section{a. Pelaksanaan Putusan}

Arbitrase merupakan suatu lembaga yang menggantikan cara kerja pengadilan. Dengan menyetujui arbitrase, para pihak meniadakan yurisdiksi pengadilan. Oleh karena itu, arbiter diberi kekuasaan untuk membuat Putusan yang mempunyai kekuatan mengikat yang sama seperti putusan pengadilan.

Dalam Pasal 59 Ayat (1) Undang-Undang No. 30 tahun 1999 disebutkan bahwa lembar asli atau salinan otentik putusan arbitrase diserahkan oleh arbiter atau kuasanya kepada Panitera Pengadilan Negeri. Hal ini berarti bahwa tanda tangan digital para pihak dan arbiter harus diotentifikasi oleh pihak ketiga oleh lembaga yang berwenang.

b. Kehadiran Saksi

Proses persidangan arbitrase online juga membutuhkan berbagai alat bukti. Alat bukti surat dan pernyataan tertulis tentu tidak akan menjadi masalah dalam berarbitrase secara online ini, karena surat dan pernyataan tersebut dapat dijadikan dokumen elektronik. Namun saksi menjadi sulit untuk didatangkan karena para pihak harus membawa 
saksinya mereka masing-masing dan berada dalam satu video conference tentu hal ini akan melemahkan kredibilitas dari saksi tersebut karena bisa saja saksi tersebut berbicara di dalam paksaan atau para saksi dapat masuk ke persidangan dengan melakukan video conference tersendiri tentu hal ini menjadi merepotkan bagi para saksi dan besar kemungkinan saksi tidak hadir.

c. Pembajakan dan Peretasan

Keamanan dalam berinternet sudah menjadi persoalan sejak dulu dikarenakan internet merupakan sarana yang sangat tidak aman. Para hacker dapat secara mudah memotong arus berarbitrase kita. Isu ini juga menjadi perhatian dalam melakukan proses berarbitrase secara online.

Peretasan (hacking) adalah upaya teknis untuk memanipulasi perilaku normal koneksi jaringan dan sistem yang terhubung. Seorang peretas adalah orang yang terlibat dalam peretasan. Istilah hacking secara historis mengacu pada pekerjaan teknis yang konstruktif dan cerdas yang tidak selalu terkait dengan sistem komputer. Bagaimanapun, peretasan paling sering dikaitkan dengan serangan pemrograman jahat pada jaringan komputer melalui koneksi internet (https://hypernet.co.id/2018/07/20/apakah-pengertian-peretasanjaringan-dan-mengapa-itu-hal-yang-buruk/ diakses pada 22 Desember 2019 pukul 20.48 WIB).

Pembajakan ini juga dapat digunakan untuk mengubah atau menghilangkan barang bukti yang akan digunakan dalam berarbitrase yang berakibat alat bukti tersebut menjadi tidak dapat digunakan dalam berarbitrase. Untuk mengetahui apakah dokumen tersebut telah diubah atau belum cukup melihat dari hash value dokumen tersebut dan dibandingkan dengan dokumen lainnya yang bersumber sama. Apabila memilihi hash value yang sama maka dokumen tersebut masih asli, begitu juga sebaliknya.

\section{d. Sarana Elektronik yang Kurang Merata}

Tentu yang menjadi hal pokok dan utama dalam pelaksanaan arbitrase secara online adalah internet, namun sekarang ini belum seluruh wilayah di Indonesia terhubung dengan internet secara merata, terdapat beberapa wilayah yang masih belum atau minim sekali koneksi internet. Survei yang dilakukan oleh Asosiasi Penyelenggara Jasa Internet (APJII) menyebut penetrasi pengguna internet di Indonesia mencapai $64,8 \%$ di tahun 2018 . Sehingga hanya 143,26 juta dari total 240 juta penduduk di Indonesia yang sudah mencicipi internet. Hal tersebut juga dikarenakan oleh layanan internet yang belum menyentuh ke daerah mereka. Dari $64,8 \%$ pengguna internet tersebut kontribusi pengguna internet per wilayah paling banyak terdapat di pulau Jawa yakni mencapai $55 \%$, kemudian disusul oleh Sumatera mencapai $21 \%$, Sulawesi- Maluku-Papua mencapai 10\%, Kalimantan mencapai 9\%, serta Bali dan Nusa Tenggara mencapai 5\% (https://katadata.co.id/berita/2019/05/16/survei-apjii- penetrasipengguna-internet-di-indonesia-capai-648 diakses pada 22 Desember 2019 pukul 20.04 WIB).

Berdasarkan data tersebut, layanan internet di Indonesia masih belum merata yang dapat menghambat bagaimana proses beracara dalam arbitrase secara online yang sangat bergantung pada koneksi internet. Karena bisa saja koneksi internet menjadi tidak lancar dan bahkan terputus di tengah berjalannya pemeriksaan.

\section{Simpulan}

Arbitrase online tidak diatur secara tegas dalam sistem peraturan perundang-undangan di Indonesia tetapi Undang- Undang No. 30 Tahun 1999 tentang Arbitrase dan Alternatif penyelesaian sengketa tidak melarang adanya fleksibilitas dalam pelaksanaan dan cara berarbitrase yang memungkinkan cara berarbitrase secara online. Hal ini juga didukung oleh Undang-undang No. 11 tahun 2008 tentang Informasi dan Transaksi Elektronik dan Undang-undang No. 19 Tahun 2016 tentang Perubahan atas Undang-undang No. 11 tahun 2008 tentang Informasi dan Transaksi 
Elektronik mengenai dokumen elektronik, tanda tangan elektronik, dan dokumen elektronik sebagai alah bukti yang tentu digunakan dalam berarbitrase secara online. Pelaksanaan Arbitrase Online juga akan muncul berbagai permasalahan seperti Pelaksanaan Putusan arbitrase online, Kehadiran Saksi, Pembajakan dan Peretasan, Sarana Elektronik yang Kurang Merata.

\section{E. Saran}

1. Kepada Badan Legislatif segera membuat peraturan atau memperbaharui Undang- Undang No. 30 Tahun 1999 tentang Arbitrase dan Alternatif Penyelesaian Sengketa agar dapat menjadi fondasi hukum berjalannya Arbitrase Online di Indonesia.

2. Kepada Presidoen untuk segera memberikan sarana pendukung dan infrastruktur telekomunikasi untuk berarbitrase secara online seperti pemerataan jaringan internet, meningkatkan kecepatan internet dan memberikan pengamanan ekstra kepada para pihak agar terlindungi dari pembajakan dan peretasan.

3. Kepada Badan Arbitrase di Indonesia untuk berani dalam menyelenggarakan arbitrase online karena pada jaman sekarang ini dibutuhkan penyelesaian sengketa yang cepat dan efisien. Terlebih transaksi dan komunikasi elektronik sudah menjadi hal yang setiap hari dilakukan oleh siapa saja.

\section{F. Daftar Pustaka}

\section{Buku}

Peter Mahmud Marzuki. 2013. Penelitian Hukum. Jakarta: Kencana Prenada Media Group.

Siburian Paustinus. 2009. Arbitrase Online: Alternatif Penyelesaian Sengketa Secara Elektronik. Jakarta: Djambatan.

\section{Jurnal}

Abdul Halim Barkatullah. 2010. "Penerapan Arbitrase Online dalam Penyelesaian Sengketa Transaksi E-Commerce". Jurnal Hukum No. 3 Vol 17. Banjarmasin : Fakultas Hukum Universitas Lambung Mangkurat Banjarmasin.

Gabrielle Kaufmann-Kohler dan Thomas Schultz. 2004. "Online Dispute Resolution: Challenges for Contemporary Justice”. Kluwer Law Internasional. Amerika : Kluwer Law Publisher.

Hetty Hassanah. Februari. 2010. "Penyelesaian Sengketa Perdagangan Melalui Arbitrase secara Elektronik (Arbitrase Online) berdasarkan Undang-Undang Nomor 30 Tahun 1999 tentang Arbitrase dan Alternatif Penyelesaian Sengketa". Jurnal Wawasan Hukum. Vol. 22. No. 01. Bandung : Sekolah Tinggi Hukum Bandung

Karolina Mania, 2015, Online Dispute Resolution: The Future of Justice, dalam International Comparative Jurisprudence Vol $1 \mathrm{hlm}$ 76-86. Belanda : Elsevier.

Mosgan Situmorang. 2017. Pelaksanaan Putusan Arbitrase Nasional di Indonesia. Jurnal Penelitian Hukum De Jure Vol. 17 No. 4 Desember 2017:309-320. Jakarta: Kementrian Hukum dan HAM.

Rizky Novian Margono. 2013. "Pengembangan Hukum Penyelesaian Sengketa Bisnis dengan Metode Arbitrase Online di Indonesia". Naskah Publikasi. Samarinda : Program Studi IImu Hukum Universitas Mulawarman.

Sarah Meilita Indrani. 2017. "Keberadaan Arbitrase Online sebagai Cara Penyelesaian Sengketa Bisnis di Indonesia ( Studi di Badan Arbitrase Nasional Indonesia Jakarta)". Jurnal Privat Law Vol. V No 2 Juli-Desember 2017. Surakarta : Bagian Perdata Fakultas Hukum Universitas Sebelas Maret. 


\section{Website}

https://hypernet.co.id/2018/07/20/apakah-pengertian-peretasan-jaringan-dan-mengapa-itu-hal-yangburuk/ diakses pada 22 Desember 2019 pukul 20.48 WIB

https://katadata.co.id/berita/2019/05/16/survei-apjii-penetrasi-pengguna-internet-di-indonesiacapai-648 diakses pada 22 Desember 2019 pukul 20.04 WIB

https://kepaniteraan.mahkamahagung.go.id/index.php/kegiatan/1625-penanganan-perkaramahkamah-agung-2018-mencetak-rekor-baru-pencapaian-terbaik-sepanjang-sejarah-ma, diakses pada 28 Oktober 2019 pukul 12.00 